\title{
The importance of narrative supports in reading animation in the context of Daycare
}

DOI: $10.46932 / \mathrm{sfjdv2n1-042}$

Received in: November 1st, 2020

Accepted in: December 30th, 2020

\section{Cíntia Palmeira}

Pós Graduação em Arte Terapia, Universidade da Madeira

Direção Regional de Educação da Região Autónoma da Madeira

Direção: Rua dos Ilhéus, $\mathrm{n}^{\circ} 1 / \mathrm{C}, 1^{\circ}$ andar, Funchal; Portugal

E-mail: palmeira.criatividade@gmail.com

\begin{abstract}
This article aims to raise awareness on the importance of creating and dynamicing narrative supports in the promotion of emerging reading behaviors in daycare. We understand as narrative supports the gloves, boxes, carpets, aprons of stories and sensory books that, when used in the pedagogical mediation of the adult, in the Bebeteca and/or in the "Hour of the Tale", promote a playful and poetic atmosphere, assuming the space of oral reading of stories as a space for the elaboration of affections, where we know a little more of the "me and the other" and approach our culture.

It is also intended to contribute to the reflection on the role of the educator/mediator in promoting an educational project that facilitates intervention in the daycare in the emerging literacy level.
\end{abstract}

Keywords: literacy, narrative supports, daycare.

\section{INTRODUCTION}

In recent years we have seen a constant concern on the part of researchers in the field of Pedagogy of Childhood, about the quality educational contexts with children aged 0 to 6 years (Bairrão, 1995; Bredekamp, 1996; Vasconcelos, 2011). By quality education, we understand an education that privileges relationships and interactions, where the child can exercise his full citizenship, thus building his educational process (Araújo, 2011; Oliveira-Formosinho \& Araújo, 2018).

Thus, the research encourages the deepening on reflecting about the quality of educational spaces, objects, materials and pedagogical interventions offered by professionals, where the child is the focus of the intervention.

To develop and learn the child needs to interact, play, explore, communicate. This is also true for learning about reading and writing. (Teberosky \& Colomer, 2003). The development of emerging reading behaviors will only be possible if the child is exposed in his interactions with the world, to contact with reading, initially by the voice of others.

In order to be able to promote in the pre-reading child the construction of a "reader project" (Viana \& Baptista, 2017) it is important to reflect on the quality of what is read and how it is read to babies. This reflection inevitably leads to questioning about the preparation of mediators for this age group. Given that 
a significant number of children between 0 and 3 years of age attend daycare contexts, the professionals to whom they are entrusted should be able to create environments that facilitate the early relationship with books and reading. This questioning gains increased relevance to the extent that, in Portugal, day care centers are part of a private/solidarity network protected by the Ministry of Labor, Solidarity and Social Security. That is, day care centers are still considered as care institutions and not properly educational institutions.

In the recommendations of the National Council of Education, on the Education of Children from 0 to 3 years, the rapporteur Teresa Vasconcelos warns us of the need to "Invest in the quality of services and develop pedagogical lines" (recommendation 6/2011), as well as "bet on the initial and continuous training of professionals" (recommendation 9/2011). Investing in the training of professionals who care for children aged 0 to 3 years (childhood educators, assistants and girls) in terms of promoting reading will contribute to preventing social exclusion and early school leaving. It will also help to extend the "right to speak" of the little ones (Recommendation 11/2011) and to promoting literacy.

The research developed in the area of neurosciences reveals the importance of quality educational contexts for the first years of life, “... the first years of life represent a window of opportunity for an education that can make a difference in children's lives, and may even break the cycles of intergenerational poverty and be a relevant factor in achievingequity." (Shonkooff \& Meisels, 2000, cited by Formosinho, 2018, p.11). Taking advantage of this window of opportunity requires highly qualified professionals.

This article presents some proposals of collection and some narrative supports that aim to encourage the creation of Bebetecas in the context of daycare and support professionals in the exploitation of works aimed at babies.

\section{BEBETECA - THE LIBRARY OF DAYCARE}

The word Bebeteca is used to define a baby library. The Bebetecas are spaces of oral narration and growth where we know a little more about the "me and the other" and appropriate the instruments of culture (oral and written language, plastic and aesthetic language, etc.).

In Bebeteca, babies and children manipulate cloth and sensory books, play with the characters of a story apron and appropriate their narrative, explore a box of stories dazzle with the natural elements (stones, leaves, chopsticks...), grow and interact in an environment of pleasure and user-friendliness.

It is advisable that the physical space of Bebeteca is comfortable, welcoming, well lit and decorated with soft colors, carpets and cushions, where babies and children feel calm and invited to try and live with different objects that can be read. It is important that babies have access to books, which must be 
distributed on low shelves or chests, strategically positioned in a quiet area, facilitating free and intuitive access.

Are part of the collection of Bebeteca cloth books, picture books, interactive books, books with windows to open and peek, books built with the help of professionals and families. In this article we will talk about the importance of the construction and dynamic of narrative supports (gloves, boxes, aprons, story mats and sensory books), due to its great aesthetic-literary impact in the construction of emerging reading behaviors.

In the educational space of the daycare, the Bebeteca area should privilege the interactions and experiences around the book and reading activities, where babies, children, parents and professionals participate and experience democracy and full citizenship.

\section{QUALITY OF INTERACTION}

In addition to the preparation of the physical environment, it is necessary to reflect on the quality of interventions and interactions in Bebeteca. We know that children grow up with autonomy when they are inserted in an environment where they are motivated to have initiative. Thus, the interaction with books and narrative media should not have an appointment.

The educator supports the child, preparing the space, materials and giving him time for experimentation. Through this free and intuitive manipulation the child can appropriate his book or preferred narrative support, and thus consolidate emerging reading behaviors.

However, by recognizing the importance of the activities developed around reading and what has been read in promoting the children's reader project (Viana \& Baptista, 2017) childhood education professionals should boost activities in a more systematized way at the level of emerging literacy.

In a study developed by Leal, Gamelas, Peixoto and Cadima (2014) the authors state that " The emerging literacy that describes the knowledge and readingand writing skills that younger children acquire before access to conventional literacy provides the basis for the development of higher education literacy skills" (p.177). In the same study it is recommended that educators provide children in the daycare course with three approaches to intervention at the level of emerging literacy, which, according to Justice and Pullen (2003), optimize acquisitions in this area: "the joint reading of storybooks between adults and children; the organisation of play contexts enriched with literacy elements; the organization of a curriculum structured by the educator for the development of phonological awareness" (pp.178-179).

The educational space in daycare should therefore integrate a Bebeteca as a playful and affective space that, through play and play, privileges the listening of stories, the handling of sensory books, the reading of images and the sharing of rhymes and songs (which are the first step towards the construction 
of a curriculum for the development of phonological awareness), with the active participation of children in the "Hours of the Tale", being supported by the pedagogical mediation of the adult .

Rolo e Silva (2009) consider that "being writing a secondary language, it is important to develop, from the cradle, oral language, the first that we all dive. The quality of this learning will depend, to a large part, on the acquisition of written language itself" (p.118). Reading for babies is also a way of promoting the development of oral language.

\section{CHILDREN'S CHARACTERISTICS AND REQUIREMENTS}

Including a Bebeteca in each Day Care Center implies thinking about the quality of the collection and the activities that are used around the book and reading.

Children from 0 to 3 years old need not only books, but also narrative supports and reading animation activities that allow pleasurable interactions with the book. The "Time of the Tale" should be instituted as a routine in the daycare, such as food or hygiene care. Its duration must respect the natural concentration time of young children.

Below are some suggestions of books, narrative supports and activities around reading in order to encourage the creation of Bebetecas in more or less formal contexts of care for the age group from 0 to 3 years.

From 0 to 6 months, small books are advised that the child can handle safely. At this stage, books constructed with fabric/ fabric, characterized by being soft, soft and pleasant to touch, are the most suitable. It is also recommended the creation/ use of story gloves, which can facilitate the presentation of songs and rhymes indicated for this age group.

Suggestion of activities: speaking; talk; sing with and for the baby. Sing; spoil songs; create sensory tissue books and boost story gloves. In the daycare, leave books available to the baby so that you can handle freely or with the support of the adult.

From 6 to 12 months, soft books, constructed of fabric, which canassociate psychomotor challenges, known as "quiet books", which present sensory challenges that captivate children's attention on each page, continue to beappropriate. At this stage, toy books, with puppets, with pieces to fit or open and peek, are recommended and found easily in the market.

Suggested activities: talk and communicate with the baby; continue to invest in the memorial heritage of songs and lengalengas; build sensory books that explore textures, colors and natural elements; involve parents in the construction of small photo albums of family members, so that the child appropriates his personal history. 
From 1 to 2 years, books with images can be introduced so that the child recognizes everyday objects, animals and rituals that can be illustrated or constructed from photographs. While exploring the theme of animals through the work, My Animals, signed by Xavier Deneux, is a good example of a book illustrated in black and white. In fabric and with some proposals of interactivity, it is also suggested the work: The robes of Martin, from the same author.

Suggested activities: create and explore sensory books with psychomotor challenges; create story boxes using natural elements; increase the repertoire of pampered and gestured songs; build a photo album of the child's history from birth to date with the help of parents

From 2 years 3 years, the first narratives are presented and the adult mediator must tell the stories always to make room for the child to ask questions, ask questions or participate in the narration. Illustrated albums are indicated, usually cartonated, as: A very busy spider, 10 rubber ducklings, Want to play with me? (signed by Eric Carle), Mommy and Good Night to All (signed by Chris Haughton) and Good Baby Trip! (signed by Beatrice Alemagna).

Suggested activities: singing; talk; read; promote dialogue and model language; create/use boxes, rugs and story aprons, with the support of families and community, whenever possible.

According to Vianna and Ribeiro (2017), "it is the reading of stories, for and with children, the activity par excellence to develop knowledge about the printed (...) It is not enough to read to children, it is necessary to create bridges between books and life. Talk about what you read. Enjoy the words. Convey pleasure. Let emotions happen” (p.14).

For some children who, at home, are little stimulated in general and for reading in particular, daycare (and then kindergarten) plays a decisive role in the true promotion of equal opportunities.

\section{THE COLLECTION - NARRATIVE SUPPORTS AT BEBETECA}

In the spaces of oral narration with babies, Ramos and Reis (2014) suggest the use of puppets, narration with objects, flanelographs, among others, given that "the group practices of reading animation, associated with external motivation factors, play an equally relevant role in the valorization of the book, positively connoting the reading practices by the association with moments assumedly playful and entertainment" (p.157).

Thus, the creation of narrative supports (gloves, aprons, carpets, story boxes and sensory books) can support the work of oral narration in an educational context of daycare. This should be valued by education professionals, involving, whenever possible, children, families and the community, in its construction, since they are not easily available for sale in the market. 
The materials used in the construction of the narrative supports should take into account the safety of the child. Thus, it is proposed that they be flexible and pleasant to touch, being at the discretion of the educator the choice of materials, textures or colors.

It is important to enrich the sensory heritage of the child. In this sense, the manipulation of objects constructed with different materials, such as felt, ribbons, strings, beads, among others, thanks to its great sensory appeal, promote the promotion of child development.

To bring the child closer to nature and promote a greater integration of outer space, in the interior space some narrative supports must be created in order to allow the discovery and exploration of natural elements, such as: leaves, stones, pine cones, grains, tree bark, sticks, etc.

We live in a world where reading has to compete with the moving image and these supports, due to their dynamics, allow a great interactivity, thus arousing the interest of the child.

\section{SOME EXAMPLES OF NARRATIVE MEDIA:}

\subsection{STORY GLOVES:}

Using gloves as basic material (of various materials and even deirmanadas) these are then enriched with accessories that support the narratives and that constitute elements that captivate attention and representative of the characters and / or actions. They have a great enchantment potential, captivate the attention of children and/or babies, who feel pleasure in following the narrator's speech, followed by the movement of the hands that boost the tale.

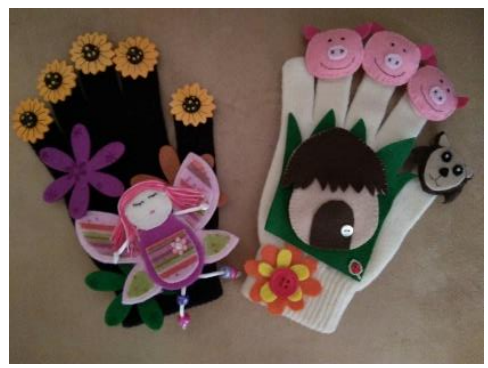

Figure 1 - Story gloves created for the song: "The spring and the flowers" and for the story "The three little pigs".

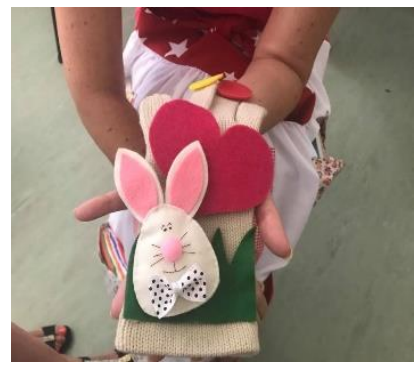

Figure 2 - Story glove created for the song "Easter Bunny you bring to me?"

We must not forget the natural enchantment provoked in children that the lullabies, the word games, the lengalengas and rhymes promote. According to Ramos (2014), "It is the oral, rhythmic and melodic component of the texts that first attracts them and it is important that this early connection be stimulated from an early age” (p.156). 
The use of story gloves can help in the development of this knowledge that has been forgotten by the modernization of societies. Maria José Costa (1992) in her work, "A forgotten poetic continent - The children's rhymes", warns us that this memorial heritage should not be despised.

According to Rolo e Silva (2009), "ancestral formulas not only teach the articulation of the sounds of language, constituting the basis of literary education, fundamental for any human being, but also create strong bonds of tenderness between adults and children. In addition, they reduce the difficulties in accessing the decoding of written language (secondary language) since the good mastery of oral language (primary language), whose acquisition begins in the family, is positively correlated with the further learning of reading." (p.120).

\subsection{STORY BOXES:}

This support has great creative and imaginative potential allowing the child to learn to discover, touch, associate and create.

The options are numerous and their construction can (and should) involve education professionals, children and families. They are a very rich pedagogical resource and enhance children's curiosity. They can be explored in small and large group or individually. They resemble a treasure chest, with various elements that together tell a story.

The story boxes can be of various dimensions: a matchbox with a small postman elf, which brings words/sounds to the group to explore; a shoebox that houses a forest built in the context of a room with natural elements (leaves, pebbles, pods, moss...), among others.

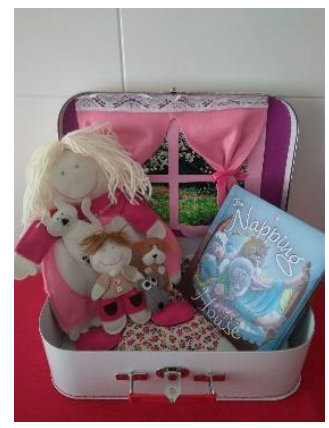

Figure 3 - Story Box created from the book: "The Napping House".

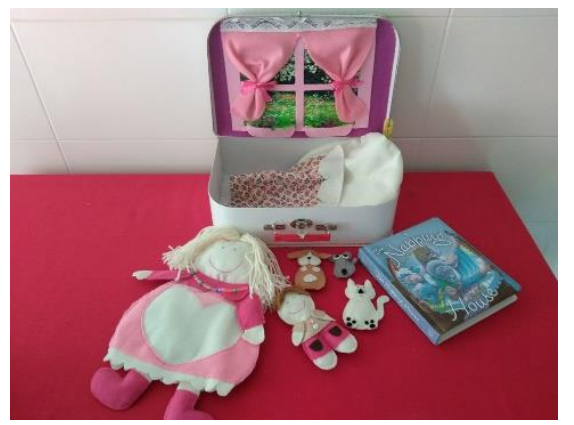

Figure 4 - The elements that are part of this box are: the book and the characters of the story: grandmother, boy, dog, cat and mouse.

In the story box above, (Figures 3 and 4) created from the book "The Napping House", the main goal is to tell and retell. At first, the tale is narrated. Then, the group of children is left to appropriate the scenery and characters, to recount or create other narratives. 
Storyboxes can also be explored as a creative writing resource (with older children). After a free space of exploration of the component elements of the box, children are invited to create a story, of which the educator makes the written record.

\subsection{SENSORY BOOKS:}

They are books created by professionals with the help or not of families and children. They promote an education by the senses thanks to their high sensory appeal. On each page, the challenges, the provocations, are presented, in an approach that calls for the participation and exploitation of babies and children. They can be constructed with cardboard, fabrics or other materials to choose from.

In the example below (Figures 5 and 6) the child explores with his hands different textures (balls, strings, buttons of various sizes, ribbons, cinnamon card, sandpaper...) in a fold-out book, attached to the wall or stretched out on the floor.

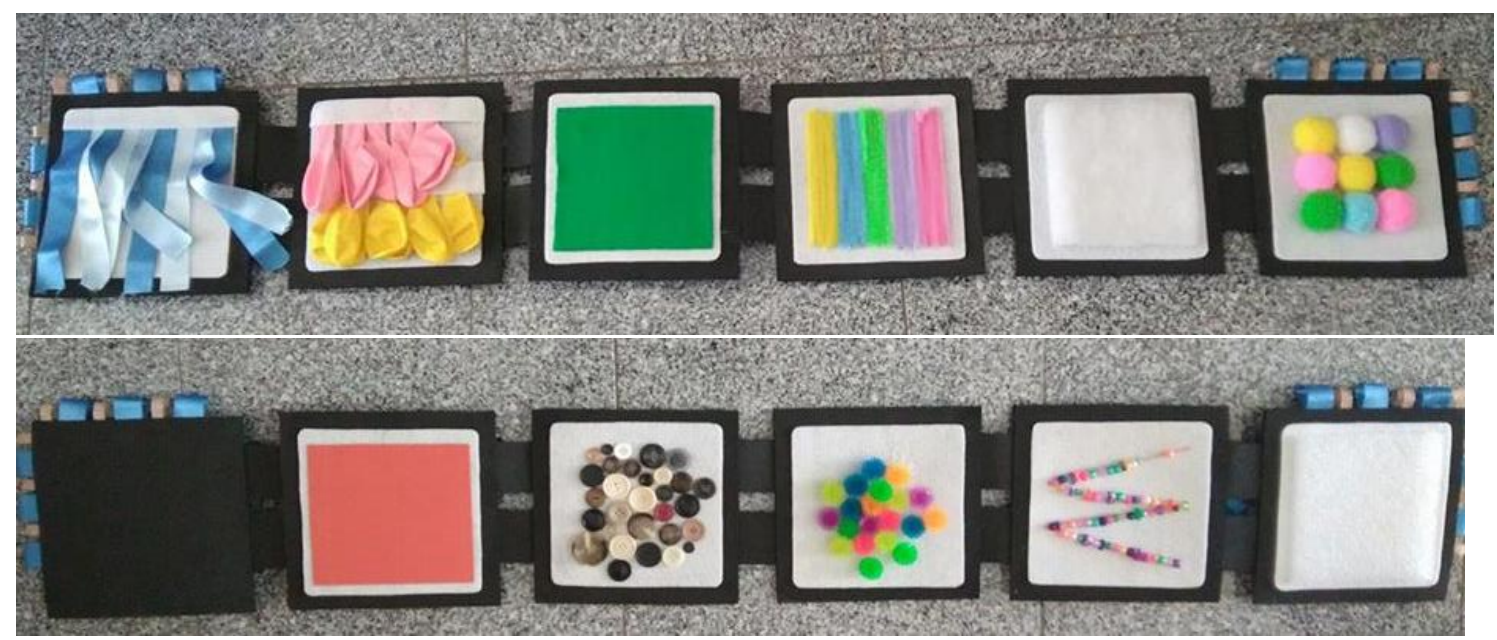

Figures 5 and 6 - sensory book that explores textures. They are part of this book: ribbons, balloons, pompoms, beads, sandpaper, plastic balls, cinnamon paper.

It is up to the pedagogical mediation of the adult, in the context of exploration, play and play, to provide children with these learnings, besides encouraging the production of comments and dialogues during their exploration. Here, the adult enriches the vocabulary of children by saying the name of the materials (sandpaper, balls, ribbons...) and what characterizes them (smooth, rough, soft...), in a quiet and empathetic environment.

Sensory books are part of the objects and materials that, when constructed with educational intentionality, appeal to "intelligent senses and sensitive intelligences of children - talking hands, thinking eyes" (Oliveira-Formosinho \& Araújo, 2018, p.34). 


\subsection{STORY APRONS:}

They are narrative supports that have the specificity of being dressed by the educator/mediator, supporting the narratives. They are characterized by the painted/stitched setting on the body of the apron. Characters can find themselves in camouflaged pockets or affixed with velcro. In this article, we will show only two types of aprons, although there are several types and styles. Story aprons can be aprons with history painted/sewn into the body of the apron (Figures 7 and 8) and/or pocket aprons (Figure 9).

Story aprons, whose story is reproduced in the body of the apron (Figures 7 and 8) due to the reduced space for manipulation, require greater savings in the number of characters that are part of the story. The inputs and outputs of the characters must be designed so that they occur in a fluid way, without harming the narration, since the excess of characters or other elements can promote noise in communication.

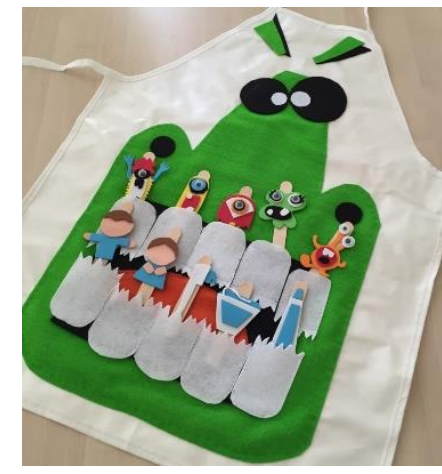

Figure 7- story "The Alligator with toothache".

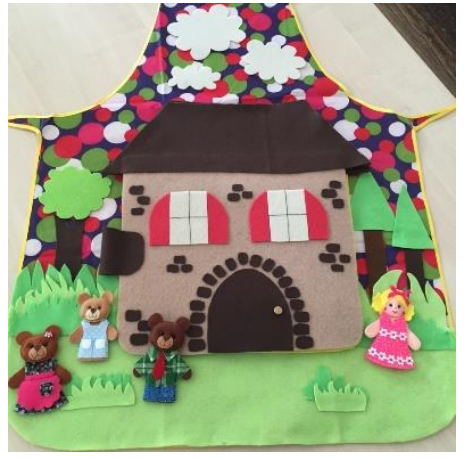

Figure 8 - traditional story "Golden Snail”.

With the story apron created for the short story "The Alligator with Toothache" (Figure 7), children immerse themselves in the universe of oral prevention. With the story apron created for "Golden Snail" (Figure 8), children get to know another narrative of the universe of traditional stories.

In the apron with pockets, (Figure 9) the element of surprise is considered a pickup of attention and curiosity in children. The mediator while reading and/or counting removes from the different pockets varied objects such as story gloves, music boxes, fold-out books, fingerbooks, among others, thus exploring different themes. 


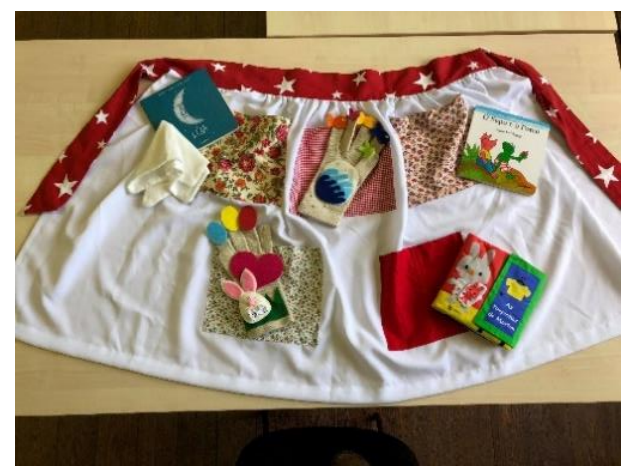

Figure 9 - Apron of pockets. They are part of this apron: two gloves of stories, the book "The Frog and the Pig", a book of cloth "The robes of the Martim" and the book "Moon".

\subsection{CARPETS OF STORIES:}

They are narrative supports that can be constructed in various dimensions based on narratives and/or songs. The scenery can be painted/sewn into fabric, as well as its characters. Due to their physical dimension, the carpets of stories allow a good viewing, thus facilitating a greater concentration and participation in the group of children.

The story is told in 3 dimensions and the characters "jump" from the pages of the book. The material dynamics of story mats provide babies and children with pleasure, surprise and enchantment, key aspects in creating an imagery bank responsible for associative capacity and creativity.

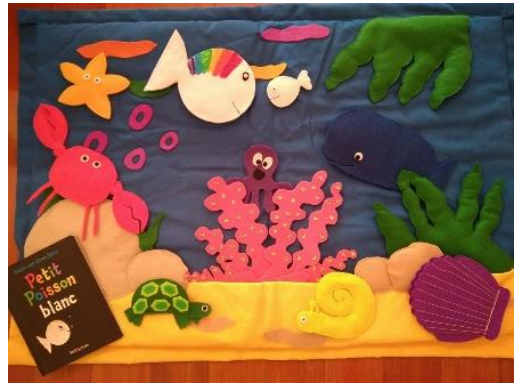

Figure 10 - Story mat: "Le petit Poison Blanc".

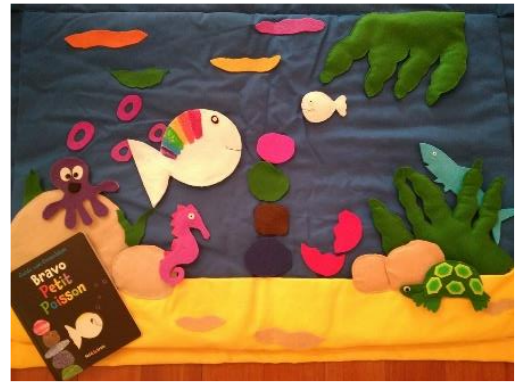

Figure 11 -Carpet of stories: "Bravo Petit Poisson".

The story mats exemplified in figures 10 and 11 were constructed from the works "Le Petit Poison Blanc" (The little white fish) and "Bravo Petit Poison" (The brave little fish). In these narratives, the author - Guido Van Genetchen - tells the adventures of a White Goldfish in an approach that appeals to affections and friendship as the way to overcome the difficulties of growth.

The same carpet, with changing accessories, can support other narratives, such as: "Viva o Peixinho" (Lucy Cousins) and "The Doctor of the Sea" (Leo Timmers). 


\section{THE DETERMINING ROLE OF THE EDUCATOR/MEDIATOR}

The professional action of the childhood educator is carried out in the joint creation of an educational project with the presence and agency of babies, children and parents.

The educator/mediator is a researcher, facilitator of experiences and learning, who promotes on their educational practice a reflection on the educational and material spaces, recognizing them as facilitators of the construction of cognitive, linguistic, social and affective knowledge.

The educator is a cultural mediator who fulfills the social role of promoter of narratives when he reads and tells his group of children different literary styles (song, poetry, fable, traditional history), thus favoring the child's encounter with his culture, without devaluing the presence of other cultures and identities.

As already mentioned, for the success of an educational project promoting literacies in the daycare center, the educator/mediator should be able to organize an appropriate collection for children aged 0 to 3 years, in addition to boosting the Bebeteca and the "Time of the Tale", which are certainly facilitating the early relationship with the book and reading.

We believe that this professional should be sensitized to the importance of the construction of pedagogical material, narrative supports (gloves, boxes, aprons, carpets, story blankets and sensory books) and know reading animation techniques that promote in the group of children in daycare a reading experience full of gesture, emotion, musicality, poetry, involving, whenever possible, families and the community.

Research reveals that in educational environments where children experience joy and well-being the levels of motivation for reading are higher. "The creation of a positive and empathic climate that arouses the interest and attention of children during activities related to written language seems to be an effective vehicle for the construction of knowledge on the part of children and, mainly, for the promotion of the taste for reading and writing..." (Viana \& Baptista, 2017, p. 14).

Even recognizing that oral reading of stories and the promotion of narrative supports usually occurs within the medium/large group, it is up to the educator/mediator to provide individualized learning spaces for the promotion of oracia and the ability to communicate. This space can happen in the context of exploration and ludicity, where the adult supports the child's attempts at vocalization and their motivation to communicate. "The indication, the repetition, the creation of a dialogue with questions and answers, in which the adult represents both roles, introduces the child to the rules of communication, modeling, little by little, the discourse." (Viana \& Baptista, 2017, p.19).

In the strategies of reading aloud, for children from 2 to 3 years, Colomer and Teberosky (2003) warn of the importance of a dialogued reading that allows the child to ask questions and actively 
participate in the process of constructing meaning. With the image feature, the child can ask "what is this?", alternating this interactive game looking for meaning with the adult, thus building an experience of linguistic and cognitive enrichment around the printed.

According to Ramos and Reis (2014), some principles and strategies should guide reading mediation for babies and children, namely:

Variety - respect for culture and the right of the child to learn, requires diversity in the collection and in the strategies of reading mediation;

Personalization - respect for the child and his individuality, his tastes and interests;

Accessibility - the right of the child to free and intuitive access always respecting his pace;

Sensory - the right to a learning of great sensory appeal, which feeds imagination and creativity. Touching, feeling, exploring, smelling, listening, are guiding words of experience;

Ludicity - the right to "play" and experience playful and affective activities around the book and reading;

Provocation, surprise - the right to amazement, to magic, through contact with books that surprise the eye thanks to their originality;

Repetition - the right to hear "more than once", to revisit a book, a song, for the pleasure of discovering and rediscovering the meaning, thus creating an intimacy with the written text, valuing the space of oral reading of stories as a space of meaning.

\section{THE EDUCATOR/MEDIATOR AND THE BRIDGES WITH THE FAMILY}

The role of the educator/mediator as a builder of social relations is decisive. In the educational space of the day care center, a space rich in literacies, affections and histories where the symbolic, aesthetics and ethics are present, families are part of the learning community.

Parents should therefore be invited to tell stories, sing songs, dramatize with puppets, and professionals are open to other suggestions for intervention. They can participate in the creation of a blanket of stories, or make, with the use of photographs, a handmade book about family experiences and/or routines, respecting the cultures inherent to each family.

Parents should also be motivated and encouraged to tell stories to their children. Watching the reading of stories by the educator is a way of modeling, with parents, behaviors and attitudes that, eventually, will not have integrated their own education. Upon realizing the potential of Bebeteca, parents will, of course, support the enrichment of this space by donating a work and /or making the necessary support for narratives or their logistics (e.g., making cushions, forging boxes, etc.). 
In short, it is intended that, in the educational space of the day care center, the area of Bebeteca is, par excellence, a place of encounter with the word and the senses, with aesthetics and ethics. It is also intended to be a space of interaction and sociability, which respects and promotes the encounter with other cultures and identities. 


\section{REFERENCES}

Araújo, S. (2011). Pedagogia em creche: Da avaliação à transformação praxiológica. Tese de Doutoramento em Estudos da Criança - Especialização em Metodologia e Supervisão de Educação de Infância. Braga: Universidade do Minho.

Bairrão, J.; Barbosa, M.; Borges, I.; Cruz, O.; Macedo-Pinto, I. (1990). Perfil Nacional dos Cuidados Prestados às Crianças com Idade Inferior a Seis anos. Lisboa: Fundação Calouste Gulbenkian.

Bredekamp, S. (1996). Developmentally Appropriete Practice en Early Chilhood Programs (NAYEC).

CNE - Conselho Nacional da Educação (2011). Recomendação sobre a Educação das Crianças dos 0 aos 3 anos (Recomendação 6,9,11/2011, Relatora Teresa Vasconcelos). Lisboa: Conselho Nacional de Educação.

Colomer, T. \& Teberosky, A. (2003). Aprender a ler e a escrever: uma proposta construtivista. Porto Alegre: Artemed.

Costa, M.J. (1992). Um Continente Poético Esquecido - As Rimas Infantis. Porto: Porto Editora.

Ferreiro, E.\&Teberosky, A. (1985). Psicogénese da língua escrita. Porto Alegre: Artes Médicas.

Formosinho, J. (2018). “A Educação em creche: O Desafio das pedagogias com Nome”, In OliveiraFormosinho, J. \& Araújo, S.B (Coords), Modelos Pedagógicos para Educação em Creche. (pp.7-27). Porto: Porto Editora.

Leal, T.; Gamelas, A.M.; Peixoto, C.\& Cadima, J. (2014). "Linguagem e literacia emergente. Propostas de promoção da leitra com bebés.”, In F. L. Viana, I. Ribeiro, \& A. Baptista, (Coords.), Ler para Ser. Os caminhos antes, durante e... depois de aprender a ler (pp. 175-205). Coimbra: Almedina

Oliveira-Formosinho, J. \& Araújo, S.B.(Coords.) (2018). Modelos Pedagógicos para Educação em Creche. Porto: Porto Editora.

Pereira, I. \& Viana, F.L. (2003). Aspectos da didática da vertente oral da língua materna no jardim de infância e no $1^{\circ}$ Ciclo do ensino Básico. Algumas reflexões. In F.F. Azevedo, R. Ramos, I. Pereira, S. Silva, M. Rosa, \& A. B. Almeida (Coords.), Actas do I Encontro Internacional A Criança, a Língua e o Texto Literário: Da Investigação às Práticas(pp.120-129). Braga: Instituto de Estudos da Criança da Universidade do Minho. Consultado a 28/01/2019 em http: hdl.handle.net/1822/4260

Ramos, A. M \& Silva, S. (2014). "Leitura do berço ao recreio. Estratégias de promoção da leitura com bebés”, In F. L. Viana, I. Ribeiro, A. Baptista (Coords.), Ler para Ser. Os caminhos antes, durante e... depois de aprender a ler (pp. 149-174). Coimbra: Almedina

Ramos, A.M. (2007). Livros de Palmo e Meio. Lisboa: Editora Caminho.

Rolo, C. \& Silva, C. (2009). “A escola e o gosto de ler. Da "obrigação” à “devoção". In F. L. Viana, \& I. Ribeiro (Coords.), Dos leitores que temos aos leitores que queremos. (pp.115-154). Coimbra: Almedina. 
Viana, F. L. (2002). Melhor falar para melhor ler. Um programa de desenvolvimento de competências linguísticas (4-6 anos). Braga: Centro de Estudos da Criança da Universidade do Minho. Acedido a 21/01/2019 em http://hdl.handle.net/1822/9354

Viana, F.L. \& Ribeiro, I. (Coords.) (2017). Falar ler e escrever. Propostas integradoras para jardim de infância. Maia: Lusoinfo Multimédia.

Alemagna, B. (2014). Boa viagem bebé. Lisboa: Orfeu Negro

Carle, E. (2017). Quer brincar comigo? Lisboa: Kalandraka Editora.

Carle, E. (2018). 10 patinhos de borracha. Lisboa: Kalandraka Editora.

Carle, E. (2018). Uma aranha muito ocupada. Lisboa: Kalandraka Editora.

Cousins, L. (2009). Viva o Peixinho. Lisboa: Editorial Caminho

Deneux, X. (2008). Os meus animais. Lisboa: Texto Editora.

Deneux, X. (2012). As roupinhas do Martim. Lisboa: Edicare Editora.

Genetchen, G.V. (2010). Le petit poison blanc. Namur: Édiçons Mijade.

Genetchen, G.V. (2010). Bravo Petit Poison Blanc. Namur: Édiçons Mijade.

Naughton, C. (2017). Mamã. Lisboa: Orfeu Negro.

Naughton, C. (2018). Boa noite a todos. Lisboa: Orfeu Negro.

Rubio, A. \& Villan, O. (2006). Lua. Kalandraka Editora.

Timmers, L. (2008). O Médico do Mar. Lisboa: Editorial Educação Nacional.

Velthuijs, M. (2011). O Sapo e o Porco. Lisboa: Editorial Caminho.

Wood, A. \& Wood, D. (2010). The Napping House. United States: HMH Books. 